\title{
Impacts of Soil Pollution on Air Quality under Nigerian Setting
}

\author{
Enetimi Idah Seiyaboh and Sylvester Chibueze Izah* \\ Department of Biological Sciences, Niger Delta University, Nigeria
}

\begin{abstract}
Soil pollution is majorly caused by human activities (viz: Agricultural practices, industrial activities and poor waste management) and natural effects such as flooding, acid rain, weathering processes. Soil pollution often cause soil barrenness, offensive odour etc. The resultant effect could impact on soil, air and water quality as well as human that reside or work close to the polluted area over a period of time depending on the physical nature of the pollutant as well as its concentration. This study reviews the impacts of soil pollution on air quality under Nigerian setting. The study found that soil pollutants from waste dumpsite could directly or indirectly cause emission of ammonia, methane, hydrogen sulphide, carbon monoxide, oxide of sulphur and nitrogen, and particulates matters into the atmosphere. Most of the aerosols have adverse effect on human health on exposure. The pollutant gases have been implicated as a major cause of respiratory related impairments. Some of the pollutant could also cause nose, eye, skin, throat irritation, cough, breathlessness, dizziness, weakness of the body and predisposed the body to certain organ dysfunctions. Soil pollutant could also aid in the transfer of pathogenic microbes that could predispose individuals residing close to soil polluted area such as dumpsite to diseases caused by microorganisms especially on immune compromised individuals. Some of the pollutant gases such as oxide of nitrogen and sulphur cause acid rain which have adverse impacts on infrastructure and biodiversity including humans than make use of the rainwater. Hence there is the need to adequately manage soil pollutants such as waste dumpsite.
\end{abstract}

\section{Keywords}

Biodiversity, Particulates, Pollutant gases, Public Health, Soil pollutants

\section{Introduction}

Environmental pollution is one of the major challenges facing humanity in the $21^{\text {st }}$ century. Industrialization, urbanization and developmental projects are the major cause of environmental pollution which is associated to anthropogenic activities have increased with the last century globally [1-4]. The different components of the environment (mainly soil, water and air) are frequently impacted by anthropogenic activities and to lesser extent natural effects. Anthropogenic activities are human activities that are carried out on the earth surface encompassing the various environmental components.

Nearly all human activities are carried out on land. Izah, et al. reported that soil is a distinctive habitat for most living organisms [5]. Although some living organisms reside in aquatic ecosystem, some species of microbes are found in varying habitats such air, soil, water, reservoirs, storage tanks, inside and within the body of human and some other animals etc. But most of the resources that are widely utilized by humanity are found in the soil. Soil also plays several economic, social, ecological roles [5,6]. The human activities on soil have direct or indirect effect on soil quality. The impacts also extend to water and air quality. Some of the notable activities that take place in the soil include construction works, erection of building structures, cultivation of vegetation, land transportation among others. As such, soil has been regarded as integral part of landscape probably due to its diverse and unique characteristics [5-7]. Soil is formed during weathering processes through the interaction of rock, geologic materials and microorganisms [8].

Soil is one of the major receipt of wastes (solid, liquid and air emission) generated from human activities. Several economic activities that lead to soil pollution are mainly from agricultural and industrial activities, and poor waste management from various processing outfit. In addition surface water are major receipt of wastes in many communities close

*Corresponding author: Sylvester Chibueze Izah, Department of Biological Sciences, Faculty of Science, Niger Delta University, Wilberforce Island, P.M.B. 071 Yenagoa, Bayelsa State, Nigeria, Tel: +234-703-0192-466

Accepted: February 11, 2019

Published online: February 13, 2019

Citation: Seiyaboh EI, Izah SC (2018) Impacts of Soil Pollution on Air Quality under Nigerian Setting. J Soil Water Sci 3(1):45-53 
to aquatic ecosystem [9-16]. Food processing such as cassava and oil palm processing wastes is predominantly dumped in soil and sometimes they block drainage systems and cause offence odours [17]. Furthermore, Izah, et al. reported that oil palm processing affect soil and surface water quality receiving the effluents. The authors also reported that it could also impact on air quality [18].

Air pollution is a major global challenge and it's more intense in developing nations. Air pollution majorly occurs when the concentration of particulate matters (PM 1, PM 2.5, PM 4, PM7, PM 10 and total particulates), volatile organic compounds (isobutylene compounds), oxides of nitrogen, sulphur, carbon, hydrogen sulphide, methane, ammonia concentration among others exceed the limits required for human health over a period of time. In developing country like Nigeria, air quality study is still in infant stage and most of the emission standard for air quality is mainly meant to checkmate the activities of oil and gas, and some selected sectors [18-21].

Air pollution is caused by both natural and anthropogenic activities. The human activities causing air pollution include fossil fuel combustion, transportation activities, industrial processes, and non-industrial fugitive sources. Non industrial activities appear to be a major contributor of air pollution that often goes unnoticed. For instance, wastes are found in several unapproved places including markets, drainage channels, undeveloped land, streets, surface water [22,23]. Ohimain and Jenakumo, Angaye, et al. Ohimain is with opinion that inadequate and irregular evacuation practices by appropriate government agencies is a contributor factor of poor waste disposal methods [22-24]. These wastes are a major cause of soil pollution.

The major processes of discharging municipal solid wastes in Nigeria depend on the locality. For instance, in most communities aligning surface water in the Niger Delta especially Bayelsa state most of the wastes generated as deposited in water ways i.e. river, creeks, creeklets $[25,26]$. In the urban areas, most of the wastes are collected and deposited in open dumpsite where they are combusted during the dry season. Instances of using municipal solid wastes to fill burrow pits also exist. Other specific wastes resulting from industrial activities such as oil and gas are often treated accordingly before being discharged into the environment. The treatment strategy for these wastes depends on its toxicity level.

Air pollution have adverse effects on humans depending on the physical constituents of the aerosols, its concentration and dispersal level. Several diseases have been associated to aerosols especially respiratory based diseases. Therefore, this study focused on the impacts of soil pollution on air quality under Nigeria setting.

\section{Causes of Soil Pollution}

Soil pollution results from natural activities and to higher extent anthropogenic activities. The rate of pollution caused human activities has surpassed the level caused by natural effects in developing country like Nigeria. This section of the paper focused on both natural and anthropogenic causes of soil pollution.

\section{Anthropogenic causes of soil pollution}

Several human activities that cause soil pollution include agricultural activities (use of pesticides-herbicides, chemical fertilizer), soil heavy metal enrichment resulting from mining activities, soil erosion after precipitation, poor management of animal wastes and general waste management, and food processing.

Use of pesticides: Pesticides are substances used in eradicating, mitigating, repelling and controlling pest in homes and agricultural field [27-37]. Pesticides have contributed a lot to pest management and agricultural enhancement in the world. The choice of pesticide depends on the type of pest to be eradicated. For instance, insecticides, miticides, larvicides, pediculicides are used to eradicate insects, herbicides are used for vegetation/herbs, acaricides is used to control ticks, molluscides is used to eradicate snails, other molluscs causing diseases, and rodenticides is used control rodents [27]. Most pesticides are produced from synthetic and semisynthetic chemicals. In the past few decades, pesticides from botanicals have been research upon and several have proven to be effect to several pests especially insects and snails $[38,39]$. Synthetic based pesticides contain chemical constituent that could be toxic to non-target organisms found in the environment [27-36]. Pesticides applied in the agricultural field and/or household setting to eradicate other pesticides could end up in other habitats or location through aerosolization, careless discharge of cans or remains, or even through runoff after rainfall [37]. Some pesticides are known to alter soil native flora. Soil play essential role in soil formation and biogeochemical cycle [8]. Pesticides on aquatic organisms could results to contamination of the water column with regard to oxygen depletion, poisoning and mass mortality of aquatic organisms such as fisheries.

Chemical fertilizers: Fertilisers are used in agricultural practices. Typically, fertilizer is used to boost crop productivity or yield. Chemical based fertilizer are used for several plants such as maize, melon, yam and cassava etc in most rural communities whose source of livelihood is agriculture in many areas in Nigeria. Most chemical based fertilizer contains several constituents that could be toxic to some soil native flora. During its application runoff after precipitation could cause it to wash to an area it's not desired causing soil pollution.

Heavy metals: Typically, heavy metals which metals that a specific gravity of $\geq 5 \mathrm{~cm}^{3}$ [40-42]. Heavy metals have been widely reported in several food materials including vegetables spices [43], fish [44-50], surface water [17,41], beverages [51], among others. Heavy metals have the tendency to persist in the environment because it's recalcitrant to degradation $[47,51]$. Heavy metals can bioaccumlate is tissues of plants and animals such as fish [42]. Most of the essential heavy metals such as chromium, zinc, copper, cobalt, iron etc are toxic to human body when their concentration exceeds the permissible level. Also, non-essential metals heavy metals such as cadmium, arsenic, lead, mercury are highly toxic 
even at low concentration in the body. Heavy metal in the environment result from anthropogenic activities and to lesser extent natural effects. Human activity leading to heavy metals deposition includes mining, quarrying of elements from their ores, wastes streams containing heavy metals.

Erosion: Soil pollutants can be transported through erosion. Emission from industrial activities could aerosolize and transported through wind effects. It could also be transported through soil erosion to other places including soil and surface water that wastes were not originally dumped. Soil pollutants could also occur through leaching of contaminant [23]. The surface water are known as major sink of many environmental pollutants.

Animal wastes: Domestic animals such as goats, cattle, are reared in open area in some locations in Nigeria. The faeces and dumped in open places where it causes odour pollution in many areas in Nigeria. Furthermore, in abattoir and slaughter house, the wastes generated are also dumped in soil where it causes attendant odour pollution.

Poor waste managements: Wastes resulting from activities of man on the environment are a major source of environmental pollution especially in developing regions. Wastes are originated from home or household item and industrial materials that are no longer and in use [16]. Improper waste management is a challenge to many developing countries. Typically, Izah and Angaye reported that large chunks of wastes are generated in several sector of the economy [42]. Three major wastes generated include solid wastes (plastic, remains of food processing, agricultural residues), liquid (effluents from industries, food sector etc) and gaseous emissions (pollutant gases) [42]. Generally, improper management of municipal wastes is a major of pollution [52-54]. Several wastes stream are dumped close to surface water. For instance, Seiyaboh and Izah reported that market wastes close to Epie creek often end up in the aquatic ecosystem blocking the water ways and causing odour pollution [16]. The impacts and pollution level depends on its constituents/composition [16]. Typically, wastes such as plastics, glass, metals, batteries, fibres and rubber are some recalcitrant non degradable wastes. Furthermore, inorganic and organic solvents in dumpsite or landfill could be deleterious to the soil as well.

Food processing: Food are fundamental resources need for human existence [55-58]. During food processing several wastes are generated especially during raw material processing. Several wastes that poorly managed are generated in several sector including food processing such as oil palm [20,21,59-64], cassava [65-70]. Specifically, oil palm processing into palm oil and kernel oil generates palm oil mill effluents (liquid wastes), chaff, empty fruit bunch, palm press fiber (solid wastes) and gaseous emissions (pollutant gases) [18]. Furthermore, during cassava processing into cassava flake or high quality cassava flour (gari), sievates and cassava peels (solid wastes), cassava mill effluents (liquid wastes) and pollutant gases gaseous emissions are generated [2-6,51,65-70]. The wastes are underutilized in most high processing countries like Nigeria, where they cause attendant environmental impacts including odour pollution and alteration of soil quality parameters.

\section{Natural cause}

In the recent times, the severity and frequency of natural hazard have increased especially in developed nations. However in the Niger Delta region of Nigeria, the impacts of soil pollution resulting from natural effects appear to predominantly cause by acid rain and water flooding. The effects of the natural cause of soil pollution appear to be triggered by human effects.

Acid rain: Several oxides of sulphur, nitrogen combine with water to form acid rain. Soil is one of the direct recipients of acid rain. Acid rain has been widely reported to be toxic to infrastructures [71]. In soil, acid rain could alter the soil acidic content thereby causing soil pollution and impacting on nonacid tolerant soil fauna. These acid rain could have impact of plant yield and productivity, distribution of abundance of fauna especially insects and soil microbes.

Flooding: Flooding is one of the major natural disasters frequently encountered in Nigeria especially resident of the coastal areas. Furthermore, most part of some cities such as Yenagoa, Aba, Warri, Lagos etc gets flooded during wet season [72]. Furthermore, the intensity of the flooding is triggered by anthropogenic activities in the area. For instance, blockage of drainage canals, erection of building in water ways or drainage system are some of the factor affecting the severity of flooding.

\section{Types of Soil Pollution}

Soil pollution occurs in several forms including barrenness of soil, offensive odour, surface being occupied by other pollutants such as solid materials, pool of water and leachate.

\section{Barrenness of land}

The soil becomes barren when they are impact by human activities and to lesser extent by natural effects. When soil becomes barren due to anthropogenic activities the characteristics of the soil is impacted. For Instance, Izah, et al., Awotoye, et al., Okwute and Isu reported that soil receiving palm mill effluents is devoid of vegetation $[18,73,74]$. Furthermore, soil receiving cassava mill effluents do not allow the growth of vegetation like non contaminated soil. When soil becomes barren its ability to support the flora and fauna is affected. It could also hinder germination of seeds as well as its productivity.

\section{Offensive odour}

Soil pollutants have the tendency to cause odour. For instance, Izah, et al., Awotoye, et al., Okwute and Isu reported that soil receiving palm mill effluents is characterized by offensive odour $[18,73,74]$. In addition, cassava processing mill often emits offensive odour that could cause stomach upset [8]. Also, waste dumpsite releases offensive odour. The odour could be highly toxic to human depending on its composition.

\section{Solid materials occupying the soil surface}

Some of the soil pollutant is solid wastes. For instance, most plastics, metals, glass, paper among others have the 
tendency to occupy space. This could hinder other useful activities that would have been carried out in the area.

\section{Effects of Soil Pollution}

Soil pollution have effects on the different major environmental components (viz: Soil, water and air quality) as well as human. This section of the paper focused on the effect of soil pollution.

\section{Soil quality}

Soil characteristics play essential role on its suitability for any activity. Several soil pollutants cause several impacts on the soil chemical parameters. Izah, et al., Awotoye, et al., Okwute and Isu reported that soil receiving palm mill effluents contain debris from processing mills, damp soil $[18,73,74]$. Studies have also indicated that cassava processing activities could alter the receiving soil characteristics $[5,8,65]$. Variation in soil characteristics could either be beneficial or detrimental to the flora and fauna is such place. For instance, Izah and Aigberua reported that cassava mill effluents decrease the population and diversity of microbes found in receiving soil [65]. This indicates that chemical composition of the pollutant could affect the fauna in soil. Also instance, of cassava mill effluents leading to reduction of plant productivity have also been reported in literatures [8]. Some of the soil pollutant could also enrich the soil with adequate nutrients leading to higher productivity.

\section{Air quality}

Soil pollution can impact on air quality. For instance, wastes dumpsite impact on air quality. Anagye, et al. reported that dumpsite emits carbon monoxide, oxide of sulphur, nitrogen and hydrogen sulphide [53]. Typically in dumpsite some of the common emission released includes carbon monoxide, oxide of sulphur and nitrogen, hydrogen sulphide, ammonia and methane (Table 1). The emission from waste dumpsite could also be as a result of decomposition of the various wastes through the interaction of the microbes found in the waste streams. The different microbial diversity found in the waste could play essential role in the type of emission generated. Furthermore, during dry season most dumpsite are frequently set ablaze and during the combustion processes different emission are released which depends on the moisture and chemical constituents of the waste [75].

\section{Surface water}

Water is one of the essential resources required for human existence. In Nigeria the potable water sources are mainly surface water (river and stream), ground water (borehole) and rain water $[40,76,77]$. In coastal region of Nigeria, most waste stream are deposited into the surface water including sewage $[25,26,42]$ and other municipal wastes [9-12,25,26]. Most of the wastes from market end up in the surface water causing alteration in water and sediment quality.

\section{Health}

Soil is a platform through which vegetation are cultivated. Plants and animals have the tendency to bioaccumulate

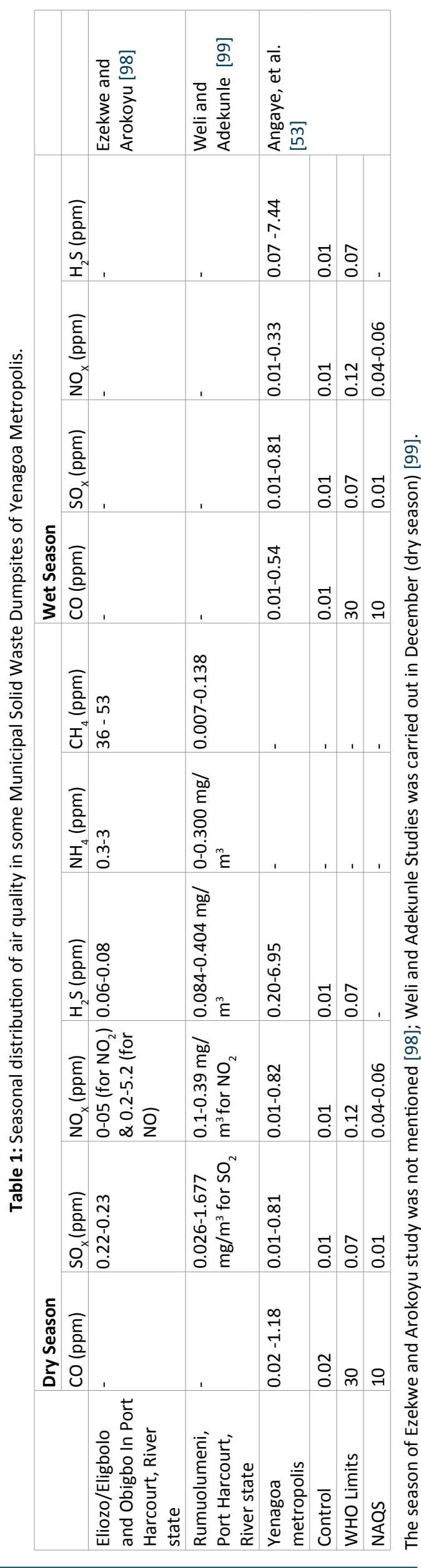


toxicants such as heavy metals in their tissues. Hence the tendency of transferring soil contaminants to the food chain is high. Though food toxicant can enter the human body causing different form of diseases that could affect reproductive, respiratory, nervous, digestive system, and poisoning that could affects body organs such as liver, and kidney.

\section{Impacts of Air Quality on Human Health}

Airborne particles are mainly from natural and anthropogenic sources. Natural sources of airborne particles are from weathering processes and dust, while anthropogenic based air borne particles is from combustion, industrial processes, manufacturing/production settings, waste dump site. These air borne particles occurs on daily basis at varying concentration depending on the meteorological parameters such as wind speed, wind direction, atmospheric temperature, among others. Some of the industrial setting that release air emission include quarrying, metal smelting, steel manufacturing, and cement batching. Air quality is frequently measured by certain parameters including oxide of nitrogen, carbon, sulphur, sulphur dioxide, ammonia, isobutylene and particulates matters. Soil pollution tends to elicit the emission of these gases. Several factor affects air quality due to soil pollution. For instance, the physical, chemical etc concentration of the pollutants in the soil could affect air quality. Furthermore, natural conditions such as moisture content of the contaminated soil could affect air quality gradients. This section of the paper focused on impact of soil pollution on air quality parameters.

\section{Particulates}

Air particulates including PM1, PM 2.5, PM 7, PM 10, and total suspended particulates have varying effect on human body. This is because the adsorption rate of the different particulate concentration differs. Several pathological effects are associated with air particulates especially when its concentration exceeds the recommended or desired limits. The impacts and severity of air particulates matter is due to the exposure duration, physical and chemical content of the particulates as well as concentration.

Authors have variously reported that particulate matters have increased respiratory and cardiovascular disease condition [20,78-80] including lung inflammation [81]. Authors have also reported that high rate of particulate matter causes respiratory diseases such as emphysema, pneumonia, bronchitis, asthma and respiratory tuberculosis $[20,82,83]$. Particulates have also been linked to increased hospital admissions associated with asthma-like conditions $[20,80]$.

Over a long period of time, exposure to high concentration of particulates could damage eyes, teeth, bones, and increased decline in reproduction potentials among species residing in the area and susceptibility to other disease and related environmental hazards [20,84-87]. Ana, Ohimain, et al. also reported that particulate matter could lead to vascular dysfunction, and increased thrombosis $[19,20]$.

\section{Oxide of nitrogen}

Most oxides of nitrogen are acidic in nature. For instance,
$\mathrm{NO}_{2}$ which is an acidic gas is an important pollutant gases. It's emitted from several human activities especially on polluted dumpsites (Table 1). $\mathrm{NO}_{2}$ have been linked to some environmental problems. Furthermore, $\mathrm{NO}_{2}$ is also related to increased risk of respiratory and cardiovascular diseases, and it could cause liver and kidney diseases over prolong period of time $[20,88]$. Ezekwe, et al. reported that oxide of nitrogen could react with ammonia, moisture and other compounds to form small particulates which could easily penetrate into the lungs and cause respiratory discomfort including emphysema and bronchitis, and aggravate existing heart disease [89].

\section{Oxide of carbon}

Oxide of carbon is one of the major environmental pollutants that can cause several human diseases. Carbon dioxide has been linked to greenhouse gases. Several soil pollutants such as combustion of wastes and bush burning release carbon monoxide into the atmosphere [75]. In addition incomplete combustion of carbonaceous materials or fossil fuels-gas, oil, coal and wood also released carbon monoxide into the environment. Ohimain, et al. reported that when carbon monoxide is inhaled over the desired concentration it hinder the bloods ability to carry oxygen to vital organs such as the heart and brain [20]. Furthermore, high concentration of carbon monoxide in the body could lead to the formation of carboxyhaemoglobin $[20,79]$.

\section{Volatile organic compound}

Volatile organic compounds are substances with low molecular weight and have short atmospheric life-time [20]. Furthermore, the severity of volatile organic compounds depends on the type of compound, level and duration of exposure. Authors have reported that short term exposure could lead to irritation of the sensory organs such as eyes, nose and throat $[20,90]$. Furthermore, exposure over a long period of time could predispose the person to liver and kidney problems and even cancer [20].

\section{Hydrogen sulphide}

Hydrogen sulphide is a colorless gas that is highly flammable and smells like rotten egg. It's known to cause irritation of the respiratory tracts which could lead to pulmonary edema at high concentration over a prolong period of time [91]. Acute or chronic toxicity is characterized by nausea, headaches, dizziness, vomiting, coughing, difficulty in breathing, convulsions, coma, death, and skin, nose, throat and eye irritation [91]. These symptoms depend on the exposure period and concentration.

\section{Sulphur dioxide}

Sulphur dioxide is one of the main oxides of sulphur that causes environmental degradation. Sulphur dioxide has a sharp smell, and it has the tendency to react with other compounds. For instance, it can easily react with water to form sulphuric acid. A significant amount of sulphur dioxide in the environmental emanates from anthropogenic sources such as coal, oil, gas combustion, extraction of sulphur containing compounds from its ore. It could also emanate from polluted soil. For instance, in dumpsite, due to anaerobic condition 
of some part of the area, several noxious gases are emitted as odour. In addition, sulphur dioxide also contributes in corrosion of materials especially metallic objects. Instances of sulphur dioxide emission from wastes dumpsite have been reported (Table 1). On exposure, sulphur dioxide could lead to nose, throat irritation, cough, wheezing, breathlessness [92]. Again the effects of sulphur dioxide depend on the exposure duration and concentration gradients.

\section{Ammonia}

Ammonia is one of the noxious gases. High concentration of ammonia could lead to irritation of the skin, eye, nose, throat and respiratory tract. In the respiratory tract, it causes some level of discomfort and if not properly managed it could cause obstruction of the respiratory system [93]. Skin, ingestion and inhalation are the main route ammonia exposure route. The severity of the impacts depends on the exposure duration and concentration. Ezekwe, et al. reported ammonia in the atmosphere is of serious concern [89].

\section{Methane}

Methane is another important gas that can be produced from both natural and anthropogenic activities. Typically, methane is a colorless, odourless gas that highly flammable on exposure with oxygen. Burning fossil fuels (coal, natural gas and gasoline) is a major source of methane in the environment [94]. Methane is also produced from faeces of animals such as goat, cattle, sheep. This could be due to be presence of some species of methanogen. It could also be produced in decomposition of organic materials such as remains of food. Methane can also be produced during anaerobic treatment of some food processing waste water such as palm mill effluents $[62,63,95]$ and cassava mill effluents [8]. Methane is a major greenhouse gas and it has been linked to climate change. Methane has been variously reported to be about 21 times more powerful than carbon dioxide [63]. On exposure, methane could lead to decline in oxygen content in the body thereby leading to loss of consciousness and coordination, dizziness and weakness of the body.

\section{Effects of Air pollution}

Air pollution typically causes several problems to both living and non-living things. For instance, dusts results from construction works often deposits on nearby by surfaces including infrastructures and vegetation covers. The extent of the effects depends on the physical constituents of the pollutants and dispersal mechanisms. On the living organisms perspectives, the microbes found in polluted soil such as dumpsite which are known to cause degradation of materials such as remain of food via aerobic and anaerobic techniques depending on the microbial isolates could be dispersed in the air and then cause disease condition to individuals that are exposed the soil pollutants. Studies have indicated that microorganisms are found in air around dumpsite vicinity. For instance, Igborgbor and Ogu reported the presence of Staphylococcus, Streptococcus, Micrococcus, Bacillus, Pseudomonas, Escherichia coli, Klebsiella species (bacteria), Penicillium, Aspergillus, Alternaria, Mucor, Curvularia, Rhizopus, Cladosporium species (fungi) as microbes found in dumpsite and round its vicinity (between $100-500 \mathrm{~m}$ ) is some part of Delta state [96]. Odeyemi reported the occurrence of Escherichia coli (37\%), Klebsiella species (19\%), Pseudomonas species (13\%), Serratia species (15\%), Staphylococcus species (8\%), Enterococcus species (7\%) and Salmonella species (1\%) in air quality of dumpsite and around its vicinity (between 50$150 \mathrm{~m}$ ) in some part of Ekiti state [97].

Air pollutants could affect plant reproduction and photosynthetic processes. This is because some pollutants could interfere with the cellular system of the plant causing mutation. This could lead to loss of several species. In addition, air pollutants such as oxide of sulphur and nitrogen have been implicated to cause acid rain. Due to the acidity content (low $\mathrm{pH})$, it could degrade metallic surfaces and infrastructures made with concrete [71]. Acid rain have effect on humans and biodiversity resources. Seiyaboh and Izah have reported that consumption of acid rain water could predispose the individuals exposed to risk of lung related diseases [71]. The authors reported that it could affect vegetation and aquatic organisms such as fishes. On vegetation, it affects the germination potentials, productivity and yield.

\section{Conclusion and the Way Forward}

Air pollutants are known to be major risk factor of respiratory diseases such as asthma, chronic pulmonary disease, tuberculosis, lung diseases. The effects of the air pollutants could have effect on the nervous system causing dizziness, breathlessness and neurobehavioral disorders. It's also a major risk factor to cancer that could affect different body parts. In severe cases, it could lead to cardiovascular diseases and birth disorder among pregnant women. Based on the effects, several options can be used to prevent the effect of soil pollution that could release air borne particulates into the environment. This typically involves wastes segregation and treatment using most suitable method based on the chemical, physical and biological constituents of the wastes. This is because sorting of wastes into different class will provide suitable platform of management. There is the need for sensitization about the effect of soil pollution and the resultant effect through aerosols on humans through campaign, awareness and even extensive teaching in classrooms. There is the need for adequate planning methods on the use of some materials such as fertilizers, pesticides that cause soil pollution by checking the topography of the area whether its prone to flooding and runoff, and weather condition prior to use. Practices that encourage soil erosion need to be controlled and checkmated. This could be achieved through avoiding over tilling and encouraging afforestation. Overall disposal method of animal wastes need to be channeled through biotechnology such as anaerobic digestion. Soil pollutants leading to odour pollution could be controlled through anaerobic digestion.

\section{References}

1. Qiu H (2010) Studies on the potential ecological risk and homology correlation of heavy metal in the surface soil. Journal of Agricultural Science 2: 194-201.

2. Izah SC, Bassey SE, Ohimain El (2018) Ecological risk assessment 
of heavy metals in cassava mill effluents contaminated soil in a rural community in the Niger Delta Region of Nigeria. Molecular Soil Biology 9: 21-31.

3. Izah SC, Aigberua AO, Nduka JO (2018) Factors affecting the population trend of biodiversity in the Niger Delta region of Nigeria. International Journal of Avian and Wildlife Biology 3: 206-214.

4. Izah SC, Seiyaboh EI (2018) Changes in the protected areas of bayelsa state, Nigeria. International Journal of Molecular Evolution and Biodiversity 8: 1-11.

5. Izah SC, Bassey SE, Ohimain El (2017) Assessment of heavy metal in cassava mill effluent contaminated soil in a rural community in the Niger Delta region of Nigeria. EC Pharmacology and Toxicology 4: 186-201.

6. Izah SC, Bassey SE, Ohimain El (2017) Geo-accumulation index, enrichment factor and quantification of contamination of heavy metals in soil receiving cassava mill effluents in a rural community in the Niger Delta region of Nigeria. Molecular Soil Biology 8: 7-20.

7. Papazotos P, Chalkiadaki O, Chatzistamatiou EA, et al. (2016) Heavy metals in urban park soils from Athens, Greece. Bulletin of the Geological Society of Greece 50.

8. Izah SC, Bassey SE, Ohimain El (2018) Impacts of Cassava mill effluents in Nigeria. Journal of Plant and Animal Ecology 1: 1442.

9. Ogamba EN, Izah SC, Oribu T (2015) Water quality and proximate analysis of Eichhorniacrassipes from River Nun, Amassoma Axis, Nigeria. Research Journal of Phytomedicine 1: 43-48.

10. Ogamba EN, Izah SC, Toikumo BP (2015) Water quality and levels of lead and mercury in Eichhorniacrassipes from a tidal creek receiving abattoir effluent, in the Niger Delta, Nigeria. Continental Journal of Environmental Science 9: 14-26.

11. Ogamba EN, Seiyaboh El, Izah SC, et al. (2015) Water quality, phytochemistryand proximate constituents of Eichhorniacrassipes from Kolo creek, Niger Delta, Nigeria. International Journal of Applied Research and Technology 4: 77-84.

12. Agedah EC, Ineyougha ER, Izah SC, et al. (2015) Enumeration of total heterotrophic bacteria and some physico-chemical characteristics of surface water used for drinking sources in Wilberforce Island, Nigeria. Journal of Environmental Treatment Techniques 3: 28-34.

13. Seiyaboh EI, Izah SC,Oweibi S (2017) Assessment of water quality from Sagbama Creek, Niger Delta, Nigeria. Biotechnological Research 3: 20-24.

14. Seiyaboh El, Izah SC, Bokolo JE (2017) Bacteriological quality of water from river nun at AmassomaAxises, Niger Delta, Nigeria. ASIO Journal of Microbiology, Food Science \& Biotechnological Innovations 3: 22-26.

15. Seiyaboh El, Izah SC (2017) Bacteriological assessment of a tidal creek receiving slaughterhouse wastes in Bayelsa state, Nigeria. Journal of Advances in Biology and Biotechnology 14: 1-7.

16. Seiyaboh El, Izah SC (2017) Review of impact of Anthropogenic activities in surface water resources in the Niger Delta region of Nigeria: A case of Bayelsa state. International Journal of Ecotoxicology and Ecobiology 2: 61-73.

17. Izah SC, Ohimain El (2015) Bioethanol production from cassava mill effluents supplemented with solid agricultural residues using bakers' yeast (Saccharomyces cerevisiae). Journal of
Environmental Treatment Techniques 3: 47-54.

18. Izah SC, Angaye TCN, Ohimain El (2016) Environmental impacts of oil palm processing in nigeria. Biotechnological Research 2: 132-141.

19. Ana GR (2011) Air pollution in the niger delta area: Scope, challenges and remedies. In: Khallaf $M$, The impact of air pollution on health, economy, environment and agricultural sources. 182-198.

20. Ohimain El, Izah SC, Abah SO (2013) Air quality impacts of smallholder oil palm processing in Nigeria. Journal of Environmental Protection 4: 83-98.

21. Ohimain El, Izah SC (2013) Gaseous emissions from a semimechanized oil palm processing mill in Bayelsa state, Nigeria. Continental Journal of Water, Air and Soil Pollution 4: 15-25.

22. Ohimain El, Jenakumo CB (2013) Scrap metal recycling and valorization in Bayelsa State, Nigeria. The Journal of Materials Science 119: 137-147.

23. Angaye TCN, Zige DV, Izah SC (2015) Microbial load and heavy metals properties of leachates from solid wastes dumpsites in the Niger Delta, Nigeria. Journal of Environmental Treatment Techniques 3: 148-153.

24. Ohimain El (2013) Scrap iron and steel recycling in nigeria. Greener Journal of Environmental Management and Public Safety 2: 1-9.

25. Ben-Eledo VN, Kigigha LT, Izah SC, et al. (2017) Water quality assessment of Epie creek in Yenagoa metropolis, Bayelsa state, Nigeria. Archives of Current Research International 8: 1-24.

26. Ben-Eledo VN, Kigigha LT, Izah SC, et al. (2017) Bacteriological quality assessment of epie creek, niger delta region of Nigeria. International Journal of Ecotoxicology and Ecobiology 2: 102-108

27. Inyang IR, Ajimmy R, Izah SC (2017) Organosomatic index and behavioral response of heterobranchusbidorsalis exposed to rhonasate $360 \mathrm{sl}$ containing glyphosate (Isopropylamine salt glycine). ASIO Journal of Microbiology, Food Science \& Biotechnological Innovations 3: 4-8.

28. Inyang IR, Ollor AO, Izah SC (2017) Effect of diazinon on organosomatic indices and behavioural responses of clariasgariepinus (a common niger delta wetland fish). Greener Journal of Biological Sciences 7: 15-19.

29. Inyang IR, IzahSC, Johnson DT, et al. (2017) Effects of Lambda cyhalothrin on some electrolytes and metabolites in organs of Parpohiocephalus obscurus. Biotechnological Research 3: 6-10.

30. Inyang IR, Seiyaboh EI, Job UB (2017) Condition factor, organosomatic indices and behavioural abnormalities of clarias gariepinus exposed to lambda cyhalothrin. Greener Journal of Life Sciences 4: 001-005.

31. Inyang IR, Akio K, Izah SC (2016) Effect of dimethoate on lactate dehydrogenase, creatinine kinase and amylase in Clarias lazera. Biotechnol Res 2: 155-160.

32. Inyang IR, Kenobi A, Izah SC (2016) Effect of dimethoate on some selected metabolites in the brain, liver and muscle of Clarias lazera. Sky Journal of Biochemistry Research 5: 63-68.

33. Inyang IR, Obidiozo OZ, Izah SC (2016) Effects of lambda cyhalothrin on protein and albumin content in the kidney and liver of parpohiocephalus obscurus. EC Pharmacology and Toxicology 2: 148-153.

34. Inyang IR, Okon NC, Izah SC (2016) Effect of glyphosate on 
some enzymes and electrolytes in Heterobranchus bidosalis (a common African catfish). Biotechnological Research 2: 161-165.

35. Inyang IR, Thomas S, Izah SC (2016) Activities of electrolytes in kidney and liver of Clarias gariepinus exposed to fluazifop-pbutyl. Journal of Biotechnology Research 2: 68-72.

36. Inyang IR, Thomas S, Izah SC (2016) Evaluation of activities of transferases and phosphatase in plasma and organs of clarias gariepinus exposed to Fluazifop-p-Butyl. Journal of Environmental Treatment Techniques 4: 94-97.

37. Ojesanmi AS, Richard G, Izah SC (2017) Mortality rate of clarias gariepinus fingerlings exposed to 2,3-dichlorovinyl dimethyl Phosphate. Journal of Applied Life Sciences International 13: 1-6.

38. Bassey SE, Izah SC (2017) Nigerian plants with insecticidal potentials against various stages of mosquito development. ASIO Journal of Medical and Health Sciences Research 2: 7-18.

39. Izah SC, Angaye TCN (2016) Ecology of human schistosomiasis intermediate host and plant molluscicides used for control: A review. Sky J Biochem Res 5: 75-82.

40. Izah SC, Chakrabarty N, Srivastav AL (2016) A review on heavy metal concentration in potable water sources in nigeria: Human health effects and mitigating measures. Exposure and Health 8: 285-304.

41. Idris MA, Kolo BG, Garba ST, et al. (2013) Pharmaceutical industrial effluent: Heavy metal contamination of surface water in minna, niger state, Nigeria. Bulletin of Environmental Pharmacology and Life Science 2: 40-44.

42. Izah SC, Angaye TCN (2016) Heavy metal concentration in fishes from surface water in Nigeria: Potential sources of pollutants and mitigation measures. Sky J Biochem Res 5: 31-47.

43. Izah SC, Aigberua AO (2017) Comparative assessment of selected heavy metals in some common edible vegetables sold in Yenagoa metropolis, Nigeria. Journal of Biotechnology Research 3: 66-71.

44. Kigigha LT, Ebieto LO, Izah SC (2017) Health risk assessment of heavy metal in smoked Trachurus trachurus sold in Yenagoa, Bayelsa state, Nigeria. International Journal of Healthcare and Medical Sciences 3: 62-69.

45. Ogamba EN, Izah SC, Ebiowe RG (2015) Bioconcentration of Mercury, Lead and Cadmium in the bones and muscles of citharinus citharus and synodontis clarias from the amassoma axis of river nun, niger delta, nigeria. Research Journal of Pharmacology and Toxicology 1: 21-23.

46. Ogamba EN, Izah SC, Omonibo E (2016) Bioaccumulation of hydrocarbon, heavy metals and minerals in Tympanotonus fuscatus from coastal region of Bayelsa state, Nigeria. International Journal of Hydrology Research 1: 1-7.

47. Ogamba EN, Izah SC, Isimayemiema F (2016b). Bioaccumulation of heavy metals in the gill and liver of a common Niger Delta wetland fish, Clarias garepinus. British Journal of Applied Research 1: 17-20.

48. Ogamba EN, Izah SC, Ofoni-Ofoni AS (2016) Bioaccumulation of chromium, lead and cadmium in the bones and tissues of oreochromis niloticus and clarias camerunensis from ikoli creek, Niger Delta, Nigeria. Advanced Science Journal of Zoology 1: 13-16.

49. Ogamba EN, Ebere N, Izah SC (2017) Levels of lead and cadmium in the bone and muscle tissues of Oreochromis niloticus and Clarias camerunensis. EC Nutrition 7: 117-123.

50. Izah SC, Inyang IR, Angaye TCN, et al. (2017) A review of heavy metal concentration and potential health implications of beverages consumed in Nigeria. Toxics 5: 1-15.

51. Izah SC, Bassey SE, Ohimain El (2017) Changes in the treatment of some physico-chemical properties of cassava mill effluents using saccharomyces cerevisiae. Toxic 5: 28.

52. Angaye TCN, Abowei JFN (2017) Review on the environmental impacts of municipal solid waste in nigeria: Challenges and prospects. Greener Journal of Environmental Management and Public Safety 6: 018-033.

53. Angaye TCN, Daokoru-Olukole C, Abowei JFN (2018) Environmental impacts of municipal solid wastes in yenagoa metropolis, Bayelsa state, Nigeria. Biotechnol Res 4: 17-23.

54. Angaye TCN, Daokoru-Olukole C, Abowei JFM (2018) Microbiological assessment of municipal solid waste dumpsites in Yenagoa Metropolis, Bayelsa State, Nigeria. Biotechnol Res 4: 24-33.

55. Izah SC, Orutugu LA, Kigigha LT (2015) A review of the quality assessment of zobo drink consumed in Nigeria. ASIO Journal of Microbiology, Food Science and Biotechnology Innovations 1: 34-43.

56. Izah SC, Kigigha LT, Anene EK (2016) Bacteriological quality assessment of malus domestica borkh and cucumis sativus $L$. in Yenagoa Metropolis, Bayelsa state, Nigeria. British Journal of Applied Research 01: 05-07.

57. Izah SC, Kigigha LT, Okowa IP (2016) Microbial quality assessment of fermented maize Ogi (a cereal product) and options for overcoming constraints in production. Biotechnol Res 2: 81-93.

58. Aigberua AO, Alagoa KJ, Izah SC (2018) Macro nutrient composition in selected seasonings used in Nigeria. MOJ Food Processing and Technology 6: 00155.

59. Ohimain El, Izah SC, Obieze FAU (2013) Material-mass balance of smallholder oil palm processing in the niger delta, nigeria. Advance Journal of Food Science and Technology 5: 289-294

60. Ohimain EI, Izah SC (2013) Water minimization and optimization by small-scale palm oil mill in niger delta, nigeria. Journal of Water Research 135: 190-198.

61. Ohimain El, Izah SC (2014) Energy self-sufficiency of smallholder oil palm processing in nigeria. Renewable Energy 63: 426-431.

62. Ohimain El, Izah SC (2014) Potential of biogas production from palm oil mills' effluent in nigeria. Sky Journal of Soil Sciences and Environmental Management 3: 50-58.

63. Ohimain El, Izah SC (2014) Possible contributions of palm oil mill effluents to greenhouse gas emissions in nigeria. British Journal of Applied Science and Technology 4: 4705-4720.

64. Ohimain El, Izah SC (2015) Energy self-sufficiency of semimechanized oil palm processing: A case study of bayelsa palm mill, elebele, nigeria. Energy Economics Letter 2: 35-45

65. Izah SC, Aigberua AO (2017) Assessment of microbial quality of cassava mill effluents contaminated soil in a rural community in the niger delta, nigeria. EC Microbiology 13: 132-140.

66. Izah SC, Bassey SE, Ohimain EI (2017) Assessment of pollution load indices of heavy metals in cassava mill effluents contaminated soil: A case study of small-scale cassava processing mills in a rural community of the niger delta region of nigeria. Bioscience Methods 8: 1-17.

67. Izah SC, Bassey SE, Ohimain El (2017) Assessment of some selected heavy metals in saccharomyces cerevisiae biomass produced from cassava mill effluents. EC Microbiology 12: 213-223. 
68. Izah SC, Bassey SE, Ohimain EI, (2017) Cyanide and macronutrients content of saccharomyces cerevisiae biomass cultured in cassava mill effluents. International Journal of Microbiology and Biotechnology 2: 176-180.

69. Izah SC, Bassey SE, Ohimain El (2017) Amino acid and proximate composition of Saccharomyces cerevisiae biomass cultivated in cassava mill effluents. Molecular Microbiology Research 7: 20-29

70. Izah SC, Bassey SE, Ohimain El (2017) Removal of heavy metals in cassava mill effluents by saccharomyces cerevisiae isolated from palm wine. MOJ Toxicology 3: 83-87

71. Seiyaboh El, Izah SC, (2017) A review of impacts of gas flaring on vegetation and water resources in the niger delta region of nigeria. International Journal of Economy, Energy and Environment 2: 48-55.

72. Ohimain El, Izah SC, Otobotekere D (2014) Selective impacts of the 2012 water floods on the vegetation and wildlife of wilberforce island, nigeria. International Journal of Environmental Monitoring Analysis 2: 73-85

73. Awotoye OO, Dada AC,Arawomo GAO (2011) Impact of palm oil processing effluent discharging on the quality of receiving soi and rivers in south western nigeria. Journal of Applied Sciences Research 7: 111-118.

74. Okwute, LorettaO, Isu, et al. (2007) The environmental impact of palm oil mill effluent (pome) on some physico-chemical parameters and total aerobic bioload of soil at a dump site in anyigba, kogi state, nigeria. African Journal of Agricultural Research 2: 656-662.

75. Izah SC, Angaye CN, Aigberua AO, et al. (2017) Uncontrolled bush burning in the niger delta region of nigeria: Potential causes and impacts on biodiversity. International Journal of Molecular Ecology and Conservation 7: 1-15.

76. Izah SC, Srivastav AL (2015) Level of arsenic in potable water sources in nigeria and their potential health impacts: A review. Journal of Environmental Treatment Techniques 3: 15-24.

77. IzahSC, IneyoughaER (2015) A review of the microbial quality of potable water sources in nigeria. Journal of Advances in Biological and Basic Research 1: 12-19.

78. Clancy L, GoodmanP, Sinclair H, et al. (2002) Effect of air-pollution control on death rates in dublin, ireland: An intervention study. Lancet 360: 1210-1214.

79. Abelsohn A, Stieb D, Sanborn MD, et al. (2002) Identifying and managing adverse environmental health effects: 2 . Outdoor air pollution, CMAJ 166: 1161-1167.

80. Adler T (2010) Respiratory health: Measuring the health effects of crop burning. Environ Health Perspect 118: 475.

81. Mantecca P, Farina F, Moschini E, et al. (2010) Comparative acute lung inflammation induced by atmospheric PM and sizefractionated tire particle. Toxicol Lett 198: 244-254.

82. Ossai EK, Iniaghe GO, Osakwe SA, et al. (1999) pollution problems and environmental effects of chemicals. In: Ekechi, Reading in General Studies: History and philosophy of science, abraka general studies. Dept Pub DELSU Abraka, 83-86.
83. Efe SI (2008) Spatial distribution of particulate air pollution in Nigerian cities: Implications for human health. J Environ Health Res 7: 107-116.

84. Mc Aughey JJ (1997) Regional lung deposition and dose of ambient particulates in humans by particle mass and number. Research Report. AEA Technology, Aerosol Science Centre, Oxfordshire, UK.

85. Injuk J, Van Gricken R (1995) Atmospheric concentrations and deposition of heavy metals over the North Sea: A literature review. Journal of Atmospheric Chemistry 20: 179-212.

86. Pope CA III, Bates DV, Raizenne ME (1995) Health effect of particulate air pollution, time for reassessment. Environmental Health Perspectives 103: 472-480.

87. Blake DR, Rowland FS (1995) Urban leakage of liquefied petroleum gas and its impact on mexico city air quality. Science 269: 953-956.

88. Umesi NO, Ideria JT, Abah S (2009) Background concentration of NO2 prior to Construction and Operation of a Gas-Fired Gas Plant in the Niger Delta Region of Nigeria. Environment and Ecology 27: 592-602.

89. Ezekwe C I, Agbakogba A, Igbagara PW (2016) Source gas emission and ambient air quality Around the Eneka co-disposal landfill in port Harcourt, Nigeria. International Journal of Applied Chemistry and Industrial Sciences 2: 11-23.

90. Wolkoff P, Kjærgaard SK (2007) The dichotomy of relative humidity on indoor air quality. Environment International 33: 850-857.

91. (2014) Toxic substances portal-hydrogen sulfide carbonyl sulfide. Agency for Toxic Substances and Disease Registry (ATSDR) 2018.

92. (2005) Sulfur dioxide (SO2). Department of the Environment and Heritage, 2018.

93. (2005) The facts about ammonia. Department of Health Accessed, 2018.

94. (2017) Methane. Tox Town 2018.

95. Ohimain El, Izah SC (2017) A review of biogas production from palm oil mill effluents using different configurations of bioreactors. Renewable \& Sustainable Energy Reviews 70: 242253.

96. Igborgbor JC, Ogu GI (2015) Microbial assessment of air in the vicinity of some dump sites in delta state. IOSR Journal of Engineering 5: 07-15.

97. Odeyemi A T (2012) Antibiogram status of bacterial isolates from air around dumpsite of ekiti state destitute centre at ilokun, adoekiti, Nigeria. Journal of Microbiology Research 2: 12-18.

98. Ezekwe IC, Arokoyu SB (2017) Landfill emissions and their urban planning and environmental health implications in port harcourt, south-south Nigeria. Desenvolv Meio Ambiente 42: 224-241.

99. Weli VE, Adekunle $O$ (2014) Air quality in the vicinity of a landfill site in rumuolumeni, port harcourt, Nigeria. Journal of Environment and Earth Science 4: 1-9.

DOI: $10.36959 / 624 / 430$

Copyright: (C) 2019 Seiyaboh El and Izah SC. This is an open-access article distributed under the terms of the Creative Commons Attribution License, which permits unrestricted use, distribution, and reproduction in any medium, provided the original author and source are credited. 